Research Article

\title{
The Impact of Training of Medical Students on COVID- 19: Goa Medical College February 2020
}

Jagadish A Cacodcar', Akshaya V Naik2, Annet Oliveira $^{3}, \underline{\text { Khan Alfiya Noorain }}{ }^{4}$, Shanishka Aurora Diniz ${ }^{5}$

${ }^{1}$ Professor \& Head, ${ }^{2}$ Post Graduate Student, Department of Preventive and Social Medicine, Goa Medical College, Goa, India. ${ }^{3}$ District Epidemiologist, IDSP, Goa, India.

4,5 Undergraduate MBBS Student, Goa Medical College, Goa, India.

DOI: https://doi.org/10.24321/2455.7048.202028

\section{I $\quad \mathbf{N} \quad \mathbf{F} \quad \mathbf{O}$}

\section{Corresponding Author:}

Akshaya V Naik, Department of Preventive and Social Medicine, Goa Medical College, Goa, India. E-mail Id:

naikakshaya3@gmail.com

Orcid Id:

https://orcid.org/0000-0001-7820-7392

How to cite this article:

Cacodcar JA, Naik AV, Oliveira A, Noorain KA, Diniz SA. The Impact of Training of Medical Students on COVID-19: Goa Medical College February 2020. Epidem Int 2020; 5(4): 22-25.

Date of Submission: 2020-07-03

Date of Acceptance: 2020-12-15

\section{$\begin{array}{llllllll}\text { A } & \text { B } & \mathbf{S} & \mathbf{T} & \mathbf{R} & \mathbf{A} & \mathbf{C} & \mathbf{T}\end{array}$}

Background: Coronavirus disease (COVID-19) is an infection caused by a newly found strain of coronavirus which is now named as SARS CoV- 2 . Since there is no cure yet against this deadly disease, preventive measures remains the mainstay till date. Healthcare workers being the frontline workers in this pandemic need to have adequate knowledge about the disease to tackle and revert this pandemic. Thus the present study aimed to assess the impact of training sessions on knowledge and attitudes towards COVID-19 among undergraduate MBBS students in Goa Medical College.

Method: The present study was a descriptive study carried out using the pre-test and post-test questionnaire that was collected during the COVID-19 training held for first year MBBS students of Goa Medical College. EpiData 3.1 was used for entry of the data. The results were analysed using SPSS software version 22.

Result: A total of 161 MBBS students participated in the study. It was seen that knowledge regarding various aspects of COVID-19 like the new nomenclature of the novel virus (28\%), symptoms (42\%), mode of spread $(78.9 \%)$, and concept of social distancing $(50.3 \%)$ was poor among the students which improved significantly after the training session.

Conclusion: With more and more ongoing researches on COVID-19 worldwide, new updates will get added to its epidemiology with time. Health care workers being the frontline workers need to keep themselves updated with the latest knowledge. Regular training sessions can enlighten the health care providers with the much needed updates which will further help to improve their skills in prevention and management of COVID-19.

Keywords: COVID-19, Training, Knowledge 


\section{Introduction}

In December 2019, cluster of pneumonia cases of unknown aetiology were reported in Wuhan province of China which was further informed to the WHO on 31 December 2019. ${ }^{1}$ On $7^{\text {th }}$ January 2020, a pathogenic human coronavirus strain SARS- CoV-2 was identified as a causative agent and the disease was named as coronavirus disease 2019 (COVID-19). On 30 January 2020, the World Health Organization declared that the outbreak of SARS-Cov-2 constituted a public health emergency of international concern (PHEIC). ${ }^{2}$

The disease causes respiratory illness (like the flu) with main clinical symptoms such as a dry cough, fever, and in more severe cases, difficulty in breathing. This disease being very contagious spreads as direct infection from coughing, sneezing and indirectly through contaminated objects, surfaces and close human contacts. However, majority of individuals infected with the COVID-19 virus may exhibit mild to moderate symptoms and recover without requiring special treatment. Older people, and those already suffering from various ailments like severe heart condition, diabetes, chronic respiratory ailment, and cancer are more likely to develop serious illness. In a study conducted by Chen et al, Median age of the deceased persons were found to be much older ( 68 years) as compared to the people who recovered from the illness (51 years). ${ }^{2}$ This outbreak was declared as pandemic by WHO on $11^{\text {th }}$ March 2020. ${ }^{3}$

No pharmaceutical products have yet been shown to be safe and effective for the treatment of COVID-19 and potential investigational therapies, many of which are now being or will soon be studied in clinical trials. ${ }^{4}$ And with vaccines still under clinical trials, ${ }^{5}$ as of now preventive measures remain the most important way to control the present pandemic which has affected almost all the countries worldwide. WHO regularly releases advisory for general public as well as health care professionals which gets updated as the epidemic evolves. It explains important preventive measures like hand hygiene, respiratory hygiene, social distancing etc. ${ }^{6}$

COVID-19 trainings of various health care workers are being carried out at various levels to strengthen the human resources as well as to prevent the spread of the disease among health care workers. Goa Medical College has held COVID-19 Trainings for various health care staff, including the under graduate medical students of their College. This study was carried among the 1 st year MBBS students who were trained on $4^{\text {th }}$ March 2020.

The Objectives of the study were as follows:

- To assess the already existing Knowledge among the medical students about COVID-19.
- To assess the attitudes and practices followed to prevent COVID-19.

- To assess the impact of the training on the medical students.

\section{Materials and Methods}

The present study was a Descriptive study carried out using the pre-test and post-test questionnaire that was collected during the COVID-19 training held for the first year MBBS students of Goa Medical College on 4th March 2020. Sampling method used was purposive sampling. All students who gave their consent to take part in the study were included as study participants.

Each questionnaire consisted of a set of 25 questions on various aspect of COVID-19. Epidata 3.1 was used for entry of the data. Frequency tables were used to assess the already existing knowledge among the medical students about COVID-19 using the pre training questionnaire. And the same questionnaire was administered after the training session to the students. Data was analysed to compare the pre training and post training questionnaire scores. The first 15 questions aimed to assess the already existing knowledge among the medical students about COVID-19 and its prevention. The post training score was used to analyse the increase in awareness on this disease. Questions 16 to 24 comprised of questions used to assess the attitudes and practices followed by medical students to prevent COVID-19; and the increase or decrease in post training test score was analysed to assess the impact of the training on the medical students.

Percentage of students who have answered the Question of the post training test correctly minus the percentage of students who have answered the same question in the pre training test correctly was analyzed to check if there was increase in knowledge of the disease.

\section{Result}

A total of 161 questionnaires were collected from those students who consented to be part of the current study. Among the study participants, majority were females (107) accounting to $66.5 \%$ and males (54) accounted for $33.5 \%$.

Majority i.e. 150 (93\%) of the medical students were already aware that the novel corona virus disease was named as COVID-19 but only 45 (28\%) knew that the correct nomenclature of the virus as SARS CoV2 but 140 (87\%) gave correct answer to that question in the post test. Majority i.e. 153 (95\%) knew that the virus originated in China but 5 more students answered it correctly in the post-test. Most of the students i.e. 127 (78.9\%) knew that the virus spreads through coughing and by fomites. The training did clear the misconception that other modes like food water insect bites and bat bites could transmit the disease which 
is seen from the fact that 156 (96.9\%) knew the correct mode of spread in the post test. Prior to the training only 68 (42\%) of the medical students knew that cough, fever and breathing in difficulty were the main symptoms of the disease whereas in the post-test 149 (92.5\%) got the correct answer.

In the pre-test, 142 (88.8\%) students knew correctly that hand washing and hand sanitizing, avoiding close contact with sick person having influenza like symptoms and covering face while coughing and sneezing were ways of preventing the infection. The percentage rose by $10 \%$ in the post-test session. Only 81 (50.3\%) knew that 2 feet constituted a close contact in the pretest and only 10 more students answered it correctly in the post-test. The awareness on availability of treatment and vaccine is summarized in Figures 1 and 2.

While analyzing the existing practices among the medical students to prevent spread of the disease it was seen that $141(87.6 \%)$ students cover their mouths with handkerchief/ tissue paper/or use the sleeve while coughing and sneezing. Also, 147 (91\%) said that they wash their hands with soap and water or use sanitizer frequently. The attitudes and perceptions in the pre-test and post-test is summarized in Table 1.

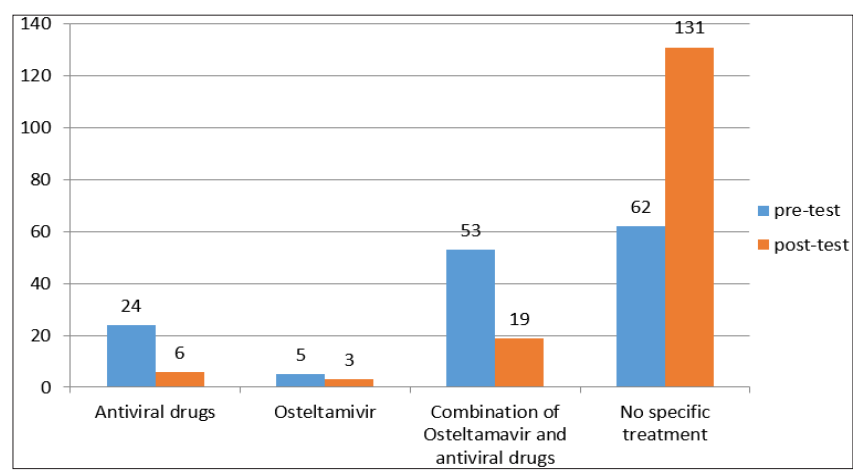

Figure I.Awareness regarding correct treatment of COVID- 19 in pre and post-test

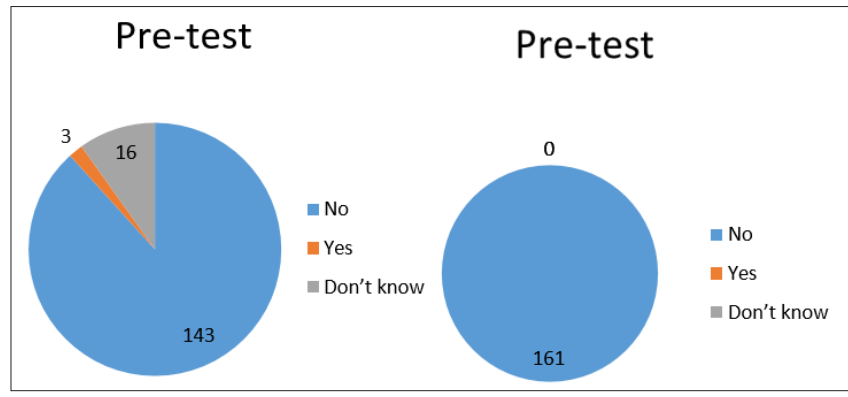

Figure 2.Awareness on the availability of approved safe vaccine among the general public

Table.Knowledge about other preventive measures in pre-training test and post-training test

\begin{tabular}{|c|c|c|c|}
\hline Preventive Measure & $\begin{array}{c}\text { No of Students } \\
\text { answered correctly } \\
\text { in Pre-test (a) }\end{array}$ & $\begin{array}{c}\text { No of Students } \\
\text { answered correctly } \\
\text { in Post-test (b) }\end{array}$ & $\begin{array}{c}\text { Increase in knowledge in } \\
\text { preventive measure by } \\
\text { percentage (b-a) }\end{array}$ \\
\hline $\begin{array}{c}\text { Isolation as a preventive step for patients } \\
\text { with symptoms of the disease }\end{array}$ & $87(54 \%)$ & $153(95 \%)$ & $41 \%$ \\
\hline $\begin{array}{c}\text { Quarantine is a preventive step for } \\
\text { asymptomatic contacts of the patient }\end{array}$ & $67(41.6 \%)$ & $155(96.3 \%)$ & $54.7 \%$ \\
\hline $\begin{array}{c}\text { The Quarantine period for people at risk is } \\
2 \text { weeks }\end{array}$ & $52(32.3 \%)$ & $142(88 \%)$ & $55.7 \%$ \\
\hline $\begin{array}{c}\text { N95 mask is recommended for } \\
\text { symptomatic cases and care givers }\end{array}$ & $52(32.3 \%)$ & $26(16.4 \%)$ & $147(91.3 \%)$ \\
\hline $\begin{array}{c}\text { N95 mask is recommended for health } \\
\text { workers dealing with symptomatic } \\
\text { patients }\end{array}$ & $85(52.8 \%)$ & $38.5 \%$ \\
\hline
\end{tabular}

Table 2.Comparison of the attitudes and perceptions of the medical students in preventing spread of COVID-19 during the pre-test and post-test

\begin{tabular}{|c|c|c|c|}
\hline $\begin{array}{c}\text { Attitude among the students to prevent } \\
\text { spread of COVID-19 }\end{array}$ & $\begin{array}{c}\text { No of students who } \\
\text { answered correctly } \\
\text { in Pre-test (b) }\end{array}$ & $\begin{array}{c}\text { No of students who } \\
\text { answered correctly } \\
\text { in Post-test (a) }\end{array}$ & $\begin{array}{c}\text { Improvement in attitude } \\
\text { towards COVID-19 by } \\
\text { percentage (b-a) }\end{array}$ \\
\hline $\begin{array}{c}\text { If you are having flu like symptoms } \\
\text { would you stay home till your symptoms } \\
\text { disappear }\end{array}$ & $98(60.9 \%)$ & $140(87 \%)$ & $42(26.1 \%)$ \\
\hline $\begin{array}{c}\text { Would you avoid a foreign travel during } \\
\text { this ongoing disease transmission }\end{array}$ & $143(88.8 \%)$ & $143(88.8 \%)$ & 0 \\
\hline
\end{tabular}




\begin{tabular}{|c|c|c|c|}
\hline $\begin{array}{c}\text { Would you shake hands to greet during } \\
\text { this ongoing disease transmission }\end{array}$ & $140(87 \%)$ & $152(94.4 \%)$ & $12(7.4 \%)$ \\
\hline Drinking alcohol can kill the virus & $147(91 \%)$ & $160(99.4 \%)$ & $13(8.4 \%)$ \\
\hline $\begin{array}{c}\text { Do you feel non-medical therapies offer } \\
\text { effective cure for the disease }\end{array}$ & $140(87 \%)$ & $152(94.4 \%)$ & $12(7.4 \%)$ \\
\hline $\begin{array}{c}\text { The virus will perish during hot Indian } \\
\text { summer }\end{array}$ & $60(37.3 \%)$ & $110(68.3 \%)$ & $50(31 \%)$ \\
\hline
\end{tabular}

Before the training only 69 (42.9\%) but after the training $130(80.7 \%)$ students said that they knew how to use the facemask correctly. Only 92 (57\%) answered correctly in the Pretest that as per WHO the level of risk of COVID-19 infection worldwide is "very high" which improved to 149 $(92.5 \%)$ in the post test assessment.

\section{Discussion}

Even though there were KAP studies among general public and studies among doctors, In Spite of extensive literature search we did not find any similar study among medical students to compare or contrast the findings of our present studies. 45 (28\%) knew that the correct nomenclature of the virus SARS CoV 2 but 140 (87\%) knew the correct answer in the post test. This shows that there $59 \%$ of the students who did not know the answer in pre-test knew it in the post test. More than $95 \%$ were already aware of the country of origin of this disease as well as the mode of transmission.

Even though 142 (88.8\%) students already correctly knew that hand washing and hand sanitizing, avoiding close contact with sick person having influenza like symptoms and covering face while coughing and sneezing were ways of preventing the infection, another $10 \%$ more students were enlightened with this preventive measures by the training.

Knowledge regarding non pharmaceutical preventive measures like isolation measures, quarantine measures, social distancing also showed marked improvement in knowledge in the post training session with rise of $41 \%$, $54.7 \%$ and $55.7 \%$ respectively. It was also noticed that there was a change in the attitude and perception towards control of COVID 19. After the training session, most of the students realised the importance of staying home when ill, greeting colleagues and friends without any physical contact.

\section{Conclusion}

It was noticed from this study that the knowledge regarding some aspects of COVID-19 was low which significantly improved after the training session was completed. With more and more ongoing researches on COVID-19 world wide, new updates gets added to its epidemiology with time. Health care workers being the frontline workers need to keep themselves updated with the latest knowledge. Regular training sessions can enlighten the health care providers with the much needed updates which will further help to improve their skills in prevention and management of COVID-19. Even other innovative methods like webinars, online zoom classes as well as mock drills on prevention and management of COVID-19 will serve as a useful educational tools in the current situation. Heath care workers should not only gather knowledge but also practice the same preventive measures for COVID-19. They can serve as a role model to educate their patients as well as general public.

\section{Acknowledgement}

We would like to acknowledge Dr. Shivanand M Bandekar, Dean, Goa Medical College for giving us permission to conduct this study among First year MBBS students.

\section{Source of Funding: None \\ Conflict of Interest: None \\ References}

1. World Health Organization- Novel Coronavirus (2019 nCoV)Situation report 1 [Internet]. 2020 [cited 2020 Jun 29]. Available from: https://www.who.int/docs/defaultsource/coronaviruse/situation-reports/20200121sitrep-1-2019-ncov.pdf?sfvrsn=20a99c10_4

2. Chen $T$, Wu D, Chen H, Yan W, Yang D, Chen G, et al. Clinical characteristics of 113 deceased patients with coronavirus disease 2019: retrospective study. BMJ [Internet]. 2020 Mar 26 [cited 2020 Jun 29];368. Available from: https://www.bmj.com/content/368/ bmj.m1091

3. Coronavirus Disease (COVID-19) [Internet]. [cited 2020 Jun 29]. Available from: https://www.who.int/india/ emergencies/coronavirus-disease-(covid-19)

4. Off-label use of medicines for COVID-19 [Internet]. [cited 2020 Jun 29]. Available from: https://www.who. int/news-room/commentaries/detail/off-label-use-ofmedicines-for-covid-19

5. Draft landscape of COVID-19 candidate vaccines [Internet]. [cited 2020 Jun 29]. Available from: https:// www.who.int/publications/m/item/draft-landscapeof-covid-19-candidate-vaccines

6. Advice for public [Internet]. [cited 2020 Jun 29]. Available from: https://www.who.int/emergencies/ diseases/novel-coronavirus-2019/advice-for-public 